\title{
Established and Advanced Adjuvants in Vaccines' Formulation: Mineral Adsorbents, Nanoparticulate Carriers and Microneedle Delivery Systems
}

\author{
Danina Krajišnik, Tanja Ilić, Ines Nikolić, Snežana Savić* \\ University of Belgrade - Faculty of Pharmacy, Department of Pharmaceutical \\ Technology and Cosmetology, Vojvode Stepe 450, 11221 Belgrade, Serbia \\ *Corresponding author: Dr Snežana Savić, Tel.: +381-11-3951288 \\ E-mail: snezana.savic@pharmacy.bg.ac.rs
}

\begin{abstract}
Summary
In the era of modern vaccinology, limited immunogenicity of the most commonly used antigens has enforced the use of various adjuvants in vaccine formulations to achieve desired immune response. Aluminum-containing adjuvants have been, historically, the most widely used mineral immunostimulants, generally regarded as safe to use in human vaccines. The great academic progress in inorganic (nano)materials synthesis, structure control and functionalization design has led to a growing interest in innovative adjuvants such as clays, mesoporous silica nanoparticles, zinc oxide, iron oxide and iron hydroxide nanoparticles, etc. On the other hand, there has been an intention to use specific nanoparticulated antigen delivery systems, such as nanoemulsions, in order to protect antigens from premature proteolytic degradation and/or to improve antigen immunogenicity by facilitating antigen uptake and processing by antigen presenting cells. Simultaneously, numerous research efforts have been focused on the development of innovative technologies for antigen delivery into the skin (such as microneedles), with the aim to improve vaccine efficacy alongside with enhanced patient adherence, particularly in children population (noninvasive or minimally invasive administration). Therefore, this review deals with each of these approaches in more detail, with the special emphasis on examples of their use in vaccine formulations as well as on the factors influencing their efficacy and safety.
\end{abstract}

Keywords: vaccine formulation, adjuvants, mineral adsorbents, nanoemulsions, Microneedles 


\section{Introduction}

It has been well established that effective and safe vaccines present an irreplaceable tool continually contributing to public and animal health worldwide, while the ongoing development of vaccines points out to the certain technological achievements during the last decades of biomedical research advancement (1). Currently, European Pharmacopoeia (supplement Ph. Eur. 9.8) counts 144 monographs of different types of vaccines intended for human and veterinary use, from which 64 monographs are those for application in human population (2). In accordance with $\mathrm{Ph}$. Eur. 9, Vaccines for human use (Vaccina ad usum humanum) are biological products that represent preparations containing antigens capable of inducing a specific and active immunity in man against an infecting agent, or the toxin or antigen elaborated by it. Immune responses include the induction of the innate and adaptive (cellular, humoral) parts of the immune system. Vaccines for human use have been shown acceptable immunogenic activity and safety within the human population taking into account the vaccination schedule (2).

Further, within the general monograph, the European Pharmacopoeia describes types of vaccines intended for human use and their different characteristics including basic principles of their production. Thus, vaccines for human use may contain: whole micro-organisms (MOs) (bacteria, viruses or parasites), inactivated by chemical and physical means that maintain adequate immunogenic properties; whole live MOs that are naturally avirulent or that have been treated to attenuate their virulence whilst retaining adequate immunogenic properties; antigens extracted from MOs or secreted from MOs or produced by genetic engineering or chemical synthesis. The antigens may be used in their native state or may be detoxified or modified by chemical or physical means, and may be aggregated, polymerised or conjugated to a carrier in order to enhance their immunogenicity. Vaccines may contain some specific adjuvant or adjuvants. Where the antigen is adsorbed on a mineral adjuvant, the vaccine is referred to as ,adsorbed” (2). Ph. Eur. 9 differs following types of vaccines: 1) Bacterial vaccines containing whole cells; 2) Bacterial vaccines containing bacterial components; 3) Bacterial toxoids; 4) Viral vaccines; 5) Synthetic antigen vaccines; 6) Combined vaccines and 7) Adsorbed vaccines (2).

Whatever the vaccine type is, vaccines authorized for the human use are clear, colourless liquids or they may be coloured or vary in opacity according to the type of preparation; further vaccines' formulation may be suspension of various degree of opacity in colourless liquid, or they may be powders produced by freezedrying/lyophilization procedure, which should be reconstituted by convenient vehicle just before the administration (2). In the most cases, vaccines are intended for parenteral administration route (intradermal vaccines), when they must be sterile, but they are also formulated for oral and nasal application (e.g. vaccine against influenza authorized for 
intranasal administration by U.S. Food and Drug Administration (FDA) in 2003 and intended for human population aged 5 - 49 years) (3). Besides, a series of intensive researches, including clinical trials, are ongoing in order to investigate and consequently to enable the application of vaccines using a transdermal route and generally skin pathways mainly involving the concept of microneedles, or sublingual as well as buccal routes and inhalation pathways. In their formulations, vaccines usually contain different pharmaceutical excipients, at the first place adjuvants and adsorbents (as a specific type of adjuvants), some stabilizers, buffers or preservatives $(2,3)$.

Although the modern vaccines are formulated in such way to possess an acceptable safety profile as much as possible, thanked to the refined purification techniques and well defined nature of antigens, it could be happened that due to the high level of purity and specificity, resulted antigens have less immunogenicity $(1,4)$. Therefore, the investigation of more effective and specific adjuvants and their incorporation into vaccines' formulations has become a standard consideration during their development.

Adjuvants are substances that when mixed with vaccines antigens, may impact through certain aspects to the enhancement of the immune responses: enabling sustained release of the given antigen dose, or allowing the antigen dose sparing, which can dramatically reduce vaccine-manufacturing costs; some of the adjuvants can adjust the vaccine formulation and make them particularly relevant to the elderly, young children and patients with chronic diseases (1). Emulsion systems of oil-in-water type (e.g. MF59 composed of squalene and two surfactants, Tween 80 and Span 85) and mineral components - adsorbents (aluminum hydroxide, aluminum phosphate and amorphous aluminum hydroxyphosphate sulfate) are used as common choice for vaccine adjuvants. Simulateously, there is an intention to apply specific advanced antigen- delivery systems (e.g. microneedles) which may improve an antigen immunogenicity, i.e. a vaccine efficacy alongside with adherence increase, particularly in children population (noninvasive or minimally invasive administration). The prospective aims of nanopartuculate systems as antigen carriers (nanoparticle-based vaccines) are based on assumptions that they could protect antigens from premature proteolytic degradation, facilitate antigen uptake and processing by antigen presenting cells, enable control release and should be safe for human use (5). Nanocarriers composed of lipids, proteins, metals or polymers are in focus and there is a need for some modification/adjustment of the critical attributes to functionalize them in order to reach an effective antigen delivery and satisfying immune response. In addition, it is of great importance to improve the performance of mineral adjuvants/adsorbents, through usage of micro- and mesoporous aluminosilicates. Apart different types of nanoparticulate carriers known as useful drug delivery systems, and therefore are considered for longer as prospective adjuvants in the vaccines' formulation development, further, a technology of controlled 
antigen release and penetration/permeation through the skin applying solid or soluble microneedles is a subject of this review $(4,5)$.

\section{Inorganic compounds as vaccine adjuvants}

Aluminum-containing adjuvants, as representatives of inorganic compounds, have been historically served as immunostimulants in vaccines and continue to be the most widely used adjuvants (6) generally regarded as safe to use in human vaccines (7). During the last decade, great academic progress in inorganic nanomaterials for vaccine adjuvants in terms of nanometer-scale synthesis, structure control, and functionalization design was achieved (8). The following section summarizes the structure, physicochemical and functional properties of currently used mineral adjuvants, relevant for their application in vaccine formulation. Additionally, a brief review of other mineral materials and novel inorganic nanoparticles which have been investigated as possible antigen carriers and adjuvants for vaccines is presented.

\subsection{Mineral Adjuvants}

Aluminum compounds and calcium phosphate are representatives of inorganic mineral compounds, which have been applied as immunological adjuvants in vaccine formulation. Of these two, the aluminum compounds have the longest history and by far the most comprehensive record of use (7).

Aluminum salts, as representatives of mineral adjuvants, have been used in human vaccines for over 70 years. Table I summarizes examples of available vaccines currently licensed for human use that employ aluminium adjuvants. A.T. Glenny and coworkers were the first to demonstrate the adjuvant effect of aluminum compounds (9). The first aluminum-adjuvanted vaccines were prepared by the addition of base to a solution of antigen (diphtheria toxoid) mixed with aluminum potassium sulfate, resulting in precipitation of the antigen and aluminum salt. Glenny observed that injecting the diphtheria toxoid as an alum precipitate led to a significant increase in the immune response against the toxoid. Although the term alum is used colloquially to refer to all aluminum adjuvants, it is technically name for aluminum potassium sulfate $\left[\mathrm{AlK}\left(\mathrm{SO}_{4}\right)_{2} \cdot 12 \mathrm{H}_{2} \mathrm{O}\right]$, which has not been widely used as an adjuvant in human vaccines (10). Vaccine preparation in accordance with this principle referred to as alumprecipitated vaccines, has been almost completely replaced by the adsorption of antigens onto preformed aluminum gels referred as aluminium-adsorbed vaccines, since this method provides a more reproducible production process, control of the adsorption and the absence of a base environment that can affect antigen stability $(7,9)$. 
Table I Examples of licensed aluminium-adjuvanted vaccines for human use $(6,9,16)$

Tabela I Primeri odobrenih vakcina sa adjuvansima na bazi aluminijuma za humanu upotrebu $(6,9,16)$

\begin{tabular}{|c|c|c|c|}
\hline Adjuvant & Vaccine & Trade name & Manufacturer \\
\hline \multirow[t]{8}{*}{ Aluminum hydroxide } & TdaP & Boostrix $^{\circledR}$ & GSK \\
\hline & DTaP & Infanrix $^{\circledR}$ & GSK \\
\hline & DTaP, Hepatitis B, polio & Pediatrix $^{\circledR}$ & GSK \\
\hline & DTaP, polio & Kinrix $^{\circledR}$ & GSK \\
\hline & Human papilloma virus & Cervarix $^{\circledR}$ & GSK \\
\hline & Hepatitis A & Havrix $^{\circledR}$ & GSK \\
\hline & Hepatitis B & Engerix $^{\circledR}$ & GSK \\
\hline & Meningococcus B & Bexsero $^{\circledR}$ & GSK \\
\hline \multirow[t]{5}{*}{ Aluminum phosphate } & $\begin{array}{l}\text { Tetanus and Diphtheria Toxoids, } \\
\text { Adsorbed }\end{array}$ & Tenivac $^{\circledR}$ & Sanofi-Pasteur \\
\hline & Pneumococcus & Prevnar $13^{\circledR}$ & Pfizer \\
\hline & Meningococcus B & Trumenba $^{\circledR}$ & Pfizer \\
\hline & DTaP & Daptacel $^{\circledR}$ & Sanofi-Pasteur \\
\hline & DTaP, polio & Quadracel $^{\circledR}$ & Sanofi-Pasteur \\
\hline \multirow{4}{*}{$\begin{array}{l}\text { Amorphous aluminum } \\
\text { hydroxyphosphate } \\
\text { sulfate }\end{array}$} & Human papilloma virus & Gardasil $^{\circledR}$ & Merck \\
\hline & Hepatitis A & VAQTA $^{\circledR}$ & Merck \\
\hline & Hepatitis B & $\begin{array}{l}\text { Recombivax } \\
\text { HB }^{\circledR}\end{array}$ & Merck \\
\hline & Haemophilus influenzae B, & PedVaxHIB $^{\circledR}$ & Merck \\
\hline $\begin{array}{l}\text { Aluminum hydroxide } \\
\text { and aluminum } \\
\text { phosphate }\end{array}$ & Hepatitis A and Hepatitis B & Twinrix $^{\circledR}$ & GSK \\
\hline
\end{tabular}

Legend: TdaP (tetanus toxoid \& reduced diphtheria toxoid \& acellular pertussis); DTaP (diphtheria toxoid \& tetanus toxoid \& acellular pertussis)

Aluminum compounds used in the lincensed vaccines (Table I) are aluminum hydroxide, aluminum phosphate and amorphous aluminum hydroxyphosphate sulfate, although these commonly used names are scientific misnomers (6). They have distinctive physicochemical properties, which have important implications for their immunomodulatory effects $(11,12)$. These adjuvants are prepared in house by vaccine companies or purchased from manufacturers by their tradenames, such as Alhydrogel ${ }^{\circledR}$, Rehydragel $^{\mathrm{TM}}$, and Adju-Phos ${ }^{\circledR}(9)$. 
Aluminum hydroxide adjuvant and aluminum phosphate adjuvant are composed of very small primary particles. However, the primary particles form aggregates that are the functioning units in vaccines (11). Commercially available aluminum hydroxide adjuvant is not $\mathrm{Al}(\mathrm{OH})_{3}$, but rather a crystalline aluminum oxyhydroxide $\mathrm{AlO}(\mathrm{OH})$ with mineralogical name of boehmite, as confirmed by X-ray diffraction and infrared spectroscopy. This difference is important because crystalline aluminum hydroxide has a low surface area (approximately 20 to $50 \mathrm{~m}^{2} / \mathrm{g}$ ) and as such a poor adsorbent properties, while crystalline aluminum oxyhydroxide has a surface area of approximately $500 \mathrm{~m}^{2} / \mathrm{g}$, which makes it an excellent adsorbent. This high surface is a result of its morphology, since the primary particles of adjuvant are fibers with average dimensions of $4.5 \times 2.2 \times 10 \mathrm{~nm}$. Aluminum oxyhydroxide is a stoichiometric compound, and it is composed of Al-OH and Al-O-Al groups. The Al-OH surface groups can accept or donate a proton, resulting in a positive or in a negative surface charge, which may affect the surface characteristics of this adjuvant (6).

Aluminum phosphate adjuvant is a chemically amorphous aluminum hydroxyphosphate $\left[\mathrm{Al}(\mathrm{OH})_{x}(\mathrm{PO} 4)_{y}\right]$ in which some of the hydroxyl groups of aluminum hydroxide are replaced by phosphate groups. The disordered, amorphous state is responsible for the high surface area and high adsorptive capacity of this adjuvant whose plate-like particles have a diameter of approximately $50 \mathrm{~nm}(11,12)$. The nanoparticles of this aluminium adjuvant form loosely connected porous aggregates that vary in size from 1 to about $20 \mu \mathrm{m}$ depending on the adjuvant, the method used for measurement of particle size, and the experimental conditions (13, 14). Another commercially available adjuvant is amorphous aluminum hydroxyphosphate sulfate, which contains residual sulfate residues because alum was used instead of aluminum chloride for its synthesis. Transmission electron microscopy revealed mesh-like structure of aluminum hydroxyphosphate sulfate (15).

Depending on the types of aluminum salts, their surface charges have notable differences (16). The isoelectric points (IEPs) of these adjuvants are 4.6-5.6, 7.4 and 11.1 for aluminum phosphate, aluminum hydroxyphosphate sulfate and aluminum hydroxide, respectively $(9,15)$. Under physiological conditions $(\mathrm{pH}=7.4)$, aluminum hydroxide is positively charged, whereas aluminum phosphate, and aluminum hydroxyphosphate sulfate are negatively charged $(6,9,11)$, which can be of great significance for interaction with antigen.

The size of the aggregate adjuvant particles can be decreased (i.e. during exposure to shear forces and ultrasonication (13) or increased when these particles are suspended in saline solution (14). The morphology of aluminum-containing adjuvants contributes to the uniform distribution of antigen in vaccines (11). The adjuvant aggregates undergo a de-aggregation and re-aggregation process during mixing. These de-aggregation and re-aggregation processes provide a mechanism that distributes antigens in mono-valent 
or combination vaccines throughout all of the adjuvant aggregates in the vaccine. Thus, even though quantities of antigen as low as $10 \mu \mathrm{g}$ are combined with quantities of adjuvant up to $0.85 \mathrm{mg} \mathrm{Al}$ during the production of a vaccine, the nature of the adjuvant aggregates provides a mechanism to uniformly distribute the antigen as long as adequate mixing procedures are followed (11). During storage at room temperature, aluminum adjuvants become more ordered due to deprotonation and dehydration. Once the physical properties of the adjuvant are known, an antigen interaction with the adjuvant can be determined (17). As a general rule, the antigen should be adsorbed onto the adjuvant prior to immunization and the adsorption should be carefully monitored (7). Adsorption of antigens to aluminum adjuvants may contribute directly to the immune-enhancing effect of aluminum adjuvants. In addition, adsorption to the adjuvant may prevent adsorption of antigens to the wall of the vial or syringe, thus ensuring injection of the full dose of antigen (9). Owing to the complex structure of antigens, it is not surprising that a number of attractive mechanisms may contribute to their adsorption (11). These mechanisms include electrostatic attraction, hydrogen bonding, hydrophobic interactions, ligand exchange and van der Waals forces $(11,17)$, while each binding force in a given antigen-adjuvant combination depends on the nature of the antigen and the chemical environment: $\mathrm{pH}$, ionic strength, presence of surfactants, etc. (7). The surface hydroxyls of aluminum hydroxide adjuvant provide the basis for the major mechanisms of adsorption of antigens: electrostatic adsorption when the antigen and adjuvant have opposite charges and ligand exchange when the antigen contains a phosphate group that is able to exchange with a hydroxyl group at the surface of the adjuvant. Electrostatic attraction is probably the most frequently used adsorption mechanism, while ligand exchange produces the strongest adsorption (6).

Determination of antigen adsorption capacity of the adjuvant is highly recommended and it can be completed by a variety of analytical methods. It is usually done by comparing the protein content in the aqueous phase of the antigen solution before and after adsorption onto the adjuvant. The amount of protein in the supernatant is simply subtracted from the amount that was initially added, to determine the amount adsorbed $(7,9)$. The adsorption of protein antigen has been typically analyzed according to the Langmuir adsorption model, which enables calculation of several adsorptive parameters, including the adsorptive coefficient, which corresponds to the strength of the antigen-adjuvant interaction. In order to correct the limitations of the Langmuir isotherm, other models (e.g. Toth isotherm, a hybrid model combining the Langmuir and the Freundlich isotherms) were later developed, that are better suited to fit data from heterogeneous systems (7).

\subsection{Formulation of vaccines with aluminium adjuvants}

When formulating a vaccine with aluminium-containing adjuvants, it is important to understand both nature of the surface of the adjuvant and how the antigen interacts 
with the surface (17). Therefore, detailed characterization of aluminum-containing adjuvants with reference to properties that affect adsorption, such as surface area, surface charge, chemical composition, structure and morphology, stability, with other colloidal behavior is essential for consistent adjuvant effect $(18,19)$. Quality specifications for aluminium adjuvants usually list parameters based on compendial testing of identity, strength, purity, etc., according to their pharmacopoeial monographs (Table II).

Table II The tests listed in general monographs (Ph. Eur. 9.0) of aluminium hydroxide adjuvant

Tabela II Ispitivanja navedena u opštoj monografiji (Ph. Eur. 9.0) aluminijum hidroksida kao adjuvansa

\begin{tabular}{|l|l|}
\hline \multicolumn{2}{|c|}{$\begin{array}{c}\text { Aluminum hydroxide, } \\
\text { (Aluminii hidroxidum hydricum ad adsorptionem) }\end{array}$} \\
\hline Test & Ph. Eur. 9.0 \\
\hline Indentification & + \\
\hline Characters & + \\
\hline Solution & + \\
\hline pH & $5.5-8.5$ \\
\hline Adsorption power & + \\
\hline Sedimentation & + \\
\hline Chlorides & $\leq 0.33 \%$ \\
\hline Nitrates & $\leq 100$ ppm \\
\hline Sulfates & $\leq 0.5 \%$ \\
\hline Ammonium & $\leq 50$ ppm \\
\hline Iron & $\leq 15$ ppm \\
\hline Bacterial endotoxins & $\begin{array}{l}\text { Less than } 5 \text { IU of endotoxin per milligram of } \\
\text { aluminium, if intended for use in the } \\
\text { manufacture of an adsorbed product without a } \\
\text { further appropriate procedure for the removal } \\
\text { of bacterial endotoxins. }\end{array}$ \\
\hline $\begin{array}{l}\text { Storage: at a temperature not exceeding } 30{ }^{\circ} \mathrm{C} \text {. Do not allow to freeze. If the supstance is a } \\
\text { Labelling: The label states the declared content of aluminium. }\end{array}$ \\
\hline Assay & \begin{tabular}{l}
$90-110 \%$ \\
\hline
\end{tabular} \\
\hline
\end{tabular}


Care must be taken in selecting a buffer for an aluminum hydroxide adjuvantcontaining vaccine (6). Phosphate anions are adsorbed by both aluminum hydroxide adjuvant and aluminum phosphate adjuvant by ligand exchange (19). Although the adsorption of antigens onto aluminum adjuvants is heavily dependent on electrostatic attraction, ligand exchange occurs with phosphorylated antigens and is the strongest adsorption force (10). The adsorption of phosphate anion present in a vaccine formulation as buffer can affect the adsorption of an antigen by affecting both the surface charge and the number of surface hydroxyls available for ligand exchange with phosphate groups of the antigen (19). Iyer et al. (20) determined the extent (adsorptive capacity) and strength (adsorptive coefficient) of adsorption for three phosphorylated proteins (alpha casein, dephosphorylated alpha casein, and ovalbumin), by the phosphate-treated aluminum hydroxide adjuvants, and found that it was inversely related to the degree of phosphate substitution of the aluminum hydroxide adjuvant. It is recommended that exposure of vaccines containing aluminum hydroxide adjuvant and phosphorylated antigens to phosphate ion in the formulation or during manufacture, should be minimized to produce maximum adsorption of the antigen. Therefore, phosphate buffer should be avoided in the formulation of vaccines with aluminium adjuvants, unless there is a specific rationale for its use (9).

Other anions of commonly used buffers that can affect adsorption include citrate, carbonate and succinate (9). Citrate buffer may lead to an increase in the soluble aluminum concentration. It was demonstrated that the citrate anion in an $\alpha$ hydroxycarboxylic acid adsorbs to an aluminum-containing adjuvant and solubilizes the aluminum by formation of a soluble aluminum-citrate complex. Buffers that do not appear to alter the properties of aluminium-containing adjuvants include acetate, histidine, MOPS (3-(N-morpholino) propanesulfonic acid) and TRIS (tromethamine) buffers $(6,9,19)$. Vaccines should be isotonic to reduce pain upon parenteral application; therefore, addition of excipients to adjust the tonicity is necessary. It has been demonstrated that ionic strength of sodium chloride solution can reduce the adsorption of electrostatically adsorbed adjuvants (21), so it is more appropriate to use a polyol rather than sodium chloride to adjust the tonicity of a vaccine containing electrostatically adsorbed antigen (11). Surfactants are frequently added to vaccine formulations to increase antigen stability. It was reported that nonionic surfactant produced less elutability of proteins from aluminium adjuvants in model vaccines compared to anionic and cationic surfactants. Although it is likely that nonionic surfactants such as polysorbate 20 and polysorbate 80 also do not affect the adsorption of antigens on aluminum hydroxide and phosphate, this needs to be further evaluated (9).

Aluminum hydroxide adjuvant and aluminum phosphate adjuvant both exhibited an increase in order during autoclaving, which resulted in a decrease in protein 
adsorption capacity. Therefore, autoclaving conditions should be selected minimizing exposure time to elevated temperatures, and procedures requiring repeated autoclaving of the same samples should be avoided (19).

Vaccines adjuvanted with aluminum salts are formulated as liquid suspensions and must remain stored in cold chain at $2-8{ }^{\circ} \mathrm{C}$ from manufacturing to being administered to patients, due to aluminium adjuvant sensitivity to freezing and freezing induced irreversible coagulation or aggregation of the gel particles $(10,22)$. Vaccines containing aluminum hydroxide adjuvant or aluminum phosphate adjuvant should not be allowed to freeze and should not be used if suspected of having been exposed to freezing temperatures $(6,23)$. Aluminum salts are suspensions of hydrated colloid particles with slow sedimentation in water due the oriented water molecules that give buoyancy and the charges on the salts, enabling electrical repulsion among the particles in the suspension (10). Freezing brings changes in the structure and morphology of the adsorbed vaccines, whether monovalent or combined. It has been proposed that ice crystals formed during freezing force aluminum particles to overcome repulsion, thereby producing strong interparticle attraction resulting in aluminum particle coagulation/agglomeration. Thus, this particles agglomerates become bigger and sediment faster than particles in non-frozen vaccines. The size of the agglomerates seems to increase on repeated freezing and thawing cycles. Adsorbed vaccines kept at the optimal temperature $\left(2-8{ }^{\circ} \mathrm{C}\right)$ show a fine-grain structure. In contrast, large conglomerates of massed precipitates with a crystalline structure are observed in vaccines affected by freezing (23). During the last two decades several technologies have been developed to overcome aluminium salt-adjuvanted vaccines sensitivity to freezing conditions $(10,22,24)$.

Calcium phosphate was initially developed by the Pasteur Institute in hydroxyapatite form $\left(\mathrm{Ca}_{10}\left(\mathrm{PO}_{4}\right)_{6}(\mathrm{OH})_{2}\right)$. X-ray diffraction, Fourier transform infrared spectroscopy, and thermal analysis of commercially available calcium phosphate (from Reheis Inc. NJ, USA) indicated that calcium phosphate adjuvant, with the suggested formula of $\mathrm{Ca}_{3}\left(\mathrm{PO}_{4}\right)_{2}$, could be described as nonstoichiometric hydroxyapatite, $\mathrm{Ca}_{10-}$ x $\left(\mathrm{HPO}_{4}\right)_{\mathrm{x}}\left(\mathrm{PO}_{4}\right)_{6-\mathrm{x}}(\mathrm{OH})_{2-\mathrm{x}}$, where $x$ varies from 0 to 2 (7). Calcium phosphate was used as an adjuvant in diphtheria, tetanus, pertussis and poliomyelitis vaccines in France, but it was completely substituted by alum salts in the late 1980s. However, it still remains as an approved adjuvant for the World Health Organization for human vaccination $(1,4,25)$, EMA (4) and Ph. Eur. (1). Adsorption capability of calcium phosphate is similar to aluminium adjuvants, and it depends on preparation method (concentration of reactants and rate at which the reactants are mixed), $\mathrm{Ca} / \mathrm{P}$ ratio, presence of hydroxyl groups, zeta potential and specific surface. The point of zero charge of calcium phosphate is 5.5, so it has a good adsorption capacity of positively charged and phosphorylated antigens. In addition, it is a biodegradable and biocompatible adjuvant 
even at a nanoscale. According to Masson et al. (25), within the next 5 years, studies and clinical trials necessary for the calcium phosphate reuse in human vaccination could be completed. This wider range would enable patients to choose an adjuvant, thus ensuring a great vaccinal coverage.

In the general monograph „Vaccines for human use” (Ph. Eur. 07/2018:1053) aluminium $(\mathrm{Al})$ content is maximum $1.25 \mathrm{mg}$ per human dose, unless otherwise stated (1). In the United States, the limit is $0.85 \mathrm{mg}$ aluminum per dose if determined by assay, $1.14 \mathrm{mg}$ if determined by calculation on the basis of the amount of aluminum compound added, and $1.25 \mathrm{mg}$ if safety and efficacy data justify it (9). The maximum allowed amount of calcium (Ca) is $1.3 \mathrm{mg}$ per human dose, unless otherwise stated (1).

\subsection{Novel inorganic nanoadjuvants as potential antigen carriers and vaccine adjuvants}

Application of clay minerals in drug delivery has been intensively investigated in last two decades due to their advantagenous physico-chemical and functional properties, such as high specific surface area, adsorption, and ion exchange, thixotropy, swelling property, chemical inertness, low toxicity and possibility of surface modification (2628). Additionally, clays have been recognized as alternative immunogen support in vaccine formulations due to their ability to increase the stabilization of immunogens that can enable easier administration and protection from proteolysis, and improved thermal and storage performance. However, it has also been observed in several studies that adsorption of antigens on pristine clays can alter their protein structure which can result in decayed immunogenicity of the antigen and eventually compromise the vaccination efficacy $(29,30)$. In order to overcome important issues related to the thermostability of vaccines and stability problems related to accidental freezing during transportation and storage, sepiolite-lipid bio-nano hybrids as novel adjuvants in thermostable influenza A vaccines were explored. In brief, these hybrids were obtained by modification of sepiolite fibres (Pangel S9 from Tolsa S.A., Spain) with a bilayer lipid membrane by contacting a $0.2 \mathrm{wt} \%$ sepiolite suspension with a $0.8 \mathrm{mM}$ liposome dispersion. Liposomes were prepared from phosphatidylcholine (Emulmetik ${ }^{\mathrm{TM}}$, Lucas Mayer GmbH, Germany) by the extrusion method (31). Improved thermal stability within functional studies at elevated temperatures up to $48^{\circ} \mathrm{C}$ was shown with enhanced resistance against lyophilization-induced antigen denaturation as often seen for alumstabilized antigens (32). This improvement in thermal stability was suggested to be related to creation of a chemical microenvironment by the sepiolite-lipid biohybrid forming a somewhat thermally protective scaffold for the adsorbed influenza virions. Fujimori et al. (33) fabricated ultrathin multilayer films of adsorbed biological molecules (enzyme lysozyme) by means of the modified Langmuir-Blodgett method using an organo-modified aluminosilicate (dimethyldioctadecylammonium modified montmorillonite platelets). The thermo-protecting effect of organoclays toward 
sensitive biological species was reported since surprisingly high thermal stability of lysozyme showing enzymatic activity until $160^{\circ} \mathrm{C}$ was determined. Clay nanoparticles, for example, layered double hydroxide (LDH) and hectorite nanoparticles, have shown their potent adjuvanticity in generating effective and durable immune responses in animal models. These findings suggest that both clay nanoadjuvants can serve as active vaccine platforms for sustained and potent immune responses (34).

The use of mesoporous silica nanoparticles (MSNs) has gained significant attention as potential delivery vehicles for various biomolecules (35). The main advantages of these materials are well-defined surface properties, high porosity, large surface area, low density, excellent biocompatibility, thermal and chemical stability (36, 37). It has been shown that introduction of MSNs as an immunoadjuvants can effectively enhance both cellular and humoral immunity in animal models $(8,38,39)$. The factors like nanoparticle architecture, antigen type, antigen loading/encapsulation, dose administered, and immunization route can influence the adjuvant properties of MSNs (35). The capacity of MSNs to induce both humoral and cell mediated immune responses over traditional adjuvants is a great advantage, and in the future, more studies are expected to evaluate the biocompatibility, stability, efficacy and biological interactions of MSNs based protein delivery system (40). Other representatives of inorganic nanoparticles such as zinc oxide, iron oxide and iron hydroxide, cobalt oxide, titanium dioxide, nanodiamond, luminescent porous silicon, guantum dots have been also in focus of academic research towards next-generation vaccines (8). In the past few years, numerous studies have also demonstrated the great potential of nanoparticles of metal-organic frameworks (nanoMOFs) at the preclinical level for biomedical applications, among other as vaccine adjuvant delivery systems (41).

\section{Nanotechnology in the development of vaccine adjuvants}

In the era of modern vaccinology, efficacious adjuvants and appropriate delivery systems for antigens are needed. In this context, nanotechnology offers some solutions (42). The need for safer and potent adjuvants resulted in the administration of an antigen within the nanoparticulated delivery systems (43). Owning to their specific features (size, shape and surface functionalities), a variety of nanoparticulated structures have been introduced as adjuvants and/or antigen delivery/presenting systems, opening the door to nanovaccinology. Among them, inorganic nanoparticles, liposomes, nanoemulsions, polymeric nanoparticles, self-assembled proteins, immunostimulating complexes and virus-like particles have been underlined as promising, and some of them have already been approved for human use $(44,45)$. In this section, nanoemulsions, as lipid-based nanostructures will be specially addressed. 


\subsection{Nanoemulsions as vaccine adjuvants}

As already described above in details, traditionally, aluminum salts are used as vaccine adjuvants with a view to boost the immune response in the presence of an antigen. Within the last two decades, nanoemulsion-based vaccine adjuvants have been shown to provide an alternative in terms of specific vaccine immunogenicity (46).

Nanoemulsions represent heterogeneous liquid systems, consisting of oil and water, stabilized by a surfactant - an amphiphilic molecule. Surfactants can be defined by their hydrophilic-lipophilic balance (HLB) value, which gives information on their relative affinity for the both phases. Oil and water form two distinct compartments, one being dispensed in the other, forming nanodroplets. They can be water-in-oil or oil-inwater $(47,48)$. These colloidal systems have been widely investigated as drug delivery systems for various administration routes: parenteral, dermal, oral, ocular, nasal (4952). In addition, nanoemulsions as excipient systems have been introduced as efficient modality for improved oral bioavailability of hydrophobic nutrients from food and food supplements $(53,54)$. Small average droplet size (generally in the range $50-300 \mathrm{~nm}$ ), high solubilization capacity, good kinetic stability, existence of several different methods for their preparation from biocompatible ingredients are just some advantages that distinguish them among other colloidal systems (48, 55-57).

As vaccine adjuvants in licenced vaccines, nanoemulsions were introduced in the 1990s, when the first emulsion-based adjuvant was registered in Europe, as a product of the company Novartis (Basel, Switzerland) (58). Nanoemulsion-based adjuvants used today in the approved vaccines are summarized in Table III. 
Table III List of nanoemulsion-based adjuvants in licensed vaccines

Tabela III Lista emulzionih adjuvanasa u vakcinama odobrenim za humanu upotrebu

\begin{tabular}{|c|c|c|c|c|c|c|}
\hline Name & Type & Components & $\begin{array}{l}\text { Size of } \\
\text { dispersed } \\
\text { phase }(\mathrm{nm})\end{array}$ & Producer & $\begin{array}{l}\text { Year } \\
\text { licensed }\end{array}$ & $\begin{array}{l}\text { Clinical } \\
\text { use }\end{array}$ \\
\hline MF59 & $\begin{array}{l}\text { Oil-in- } \\
\text { water }\end{array}$ & $\begin{array}{l}\text { squalene; } \\
\text { polysorbate } 80 ; \\
\text { sorbitantrioleate; } \\
\text { citrate buffer pH } 6.5\end{array}$ & 160 & Novartis & 1997 & $\begin{array}{l}\text { seasonal } \\
\text { influenza, } \\
\text { pandemic } \\
\text { influenza, } \\
\text { avian } \\
\text { influenza }\end{array}$ \\
\hline ASO3 & $\begin{array}{l}\text { Oil-in- } \\
\text { water }\end{array}$ & $\begin{array}{l}\text { squalene; } \\
\alpha \text {-tocopherol; } \\
\text { polysorbate } 80 \\
\text { PBS pH } 6.8\end{array}$ & 160 & GSK & 2009 & $\begin{array}{l}\text { pandemic } \\
\text { influenza, } \\
\text { avian } \\
\text { influenza }\end{array}$ \\
\hline$A F 03$ & $\begin{array}{l}\text { Oil-in- } \\
\text { water }\end{array}$ & $\begin{array}{l}\text { squalene; } \\
\text { polyoxyethylenecetostearyl } \\
\text { ether; } \\
\text { mannitol; } \\
\text { sorbitan oleate; } \\
\text { PBS pH } 7.1 \\
\end{array}$ & 90 & Sanofi & 2010 & $\begin{array}{l}\text { pandemic } \\
\text { influenza }\end{array}$ \\
\hline $\begin{array}{l}\text { Montanide }^{\mathrm{TM}} \\
\text { ISA 51VG }\end{array}$ & $\begin{array}{l}\text { Water- } \\
\text { in-oil }\end{array}$ & $\begin{array}{l}\text { mineral oil, } \\
\text { mannide monooleate } \\
\text { (Prior to use, it is mixed with } \\
\text { the conjugated antigen in the } \\
\text { PBS, forming water-in-oil } \\
\text { emulsion) }\end{array}$ & $<1 \mu \mathrm{m}$ & Seppic & 2008 & $\begin{array}{l}\text { lung } \\
\text { cancer }\end{array}$ \\
\hline
\end{tabular}

More than eighty years ago, the adjuvant effect of mineral oil (in a water-in-oil emulsion) in combination with thermally killed mycobacteria cells was demonstrated by Freund, and this adjuvant was marked as Freund's complete adjuvant (59). Afterwards, water-in-oil emulsions without the bacterial cells (Freund's incomplete adjuvant) were used as adjuvants both in human and veterinary vaccines. Additionally, there was a little knowledge on their mechanism of action, even though it was suggested that they might act as depot systems. However, despite their indisputable efficacy, they were too reactogenic for routine use $(45,58)$.

Acquired experience through the years pointed out some important characteristics that nanoemulsion-based adjuvants should possess, representing a milestone for further development. In general, efficacy of an adjuvant is determined by droplet size, oil content (oil-to-water ratio), droplet surface properties and viscosity (44, 61). It is preferred that oil phase is biodegradable, and surfactants should be recognized as safe for human use, with many years of application. Tolerability can be highly improved by 
lowering the oil content and shifting from water-in-oil to oil-in-water emulsions, which is followed by reduced viscosity, as well $(43,62)$.

Moreover, subsequent refinement of the base materials has resulted in the new versions of water-in-oil emulsions. Among the ones undergoing clinical trial assessment, the Montanide ${ }^{\mathrm{TM}}$ emulsions can be underlined (products of the company Seppic (Paris, France) - especially for therapeutic vaccines. A vaccine against nonsmall-cell lung cancer, the CimaVax EGF ${ }^{\circledR}$, using this adjuvant technology, has already been licensed (60).

\subsubsection{Physicochemical properties of nanoemulsion-based adjuvants}

Physicochemical properties of nanoemulsion direct its efficacy and safety profile as adjuvant. This includes the type of the nanoemulsion, viscosity, droplet size and surface properties (63).

The viscosity of a nanoemulsion is closely linked to the surfactant structure, its HLB value, and the ratio between the two phases. Too viscous formulations are not only difficult to be injected, but they also represent a safety issue. In general, oil-in-water nanoemulsions are characterized by lower viscosity. However, fluid water-in-oil nanoemulsions, with viscosity comparable to the viscosity of hydrophilic nanoemulsions, can be obtained if the stabilizers have optimized HLB value, corresponding to the type of selected oil (63).

Even though there are crossing opinions, it is generally accepted that droplet size may be one of the key features. Smaller size enables sterile filtration, safer parenteral administration, gives rise to more stable formulations, and finally, it reduces chances for local inflammation $(51,61,64,65)$. Much effort has been put in order to identify the ideal size of an adjuvant to elicit the highest responses. However, this topic cannot be generalized, and findings are highly dependent on the specific class of adjuvants (64). Considering nanoemulsions, in animal studies with a set of different mice strains and various antigen types, it was noted that with increase in the droplet size of the nanoemulsion, the adjuvant efficacy increases. Contrastingly, nanoemulsions with smaller droplet size are inferior adjuvants, but with better safety profile (64). In the study of Shah et al. (66) it was highlighted that there was no benefit in reducing nanoemulsion droplet size below $160 \mathrm{~nm}$ - both for humoral and cellular immune response. Taken all together - efficacy and safety profile of nanoemulsion-based adjuvants, their stability and possibility to undergo sterile filtration, it may be concluded that „smaller is not always the better”. Nevertheless, size of the nanoemulsion droplets is affected by the components, their ratio in the nanoemulsion and the preparation technique, so all these aspects should be carefully addressed during preparation of the final formulation. 


\subsubsection{Mechanism of action of nanoemulsion-based adjuvants}

On the one hand, nanoemulsions represent delivery systems, which protect the antigen and release it at the target site, enhancing the uptake of the antigen by the antigen presenting cells. On the other hand, they create an inflammation at the injection site and act as immunopotentiators, activating specific pathways (firstly of innate, and then of adaptive immunity) important for improved antigen processing $(45,60,62)$. There is also a rational hypothesis that effective immune activation by nanoemulsion adjuvants may be, at least partially, mediated by the presence of surfactant on the oil droplets. However, it was proved that none of the nanoemulsion components solely can induce appropriate response, but the complete formulation is responsible for the effect (67). In the study of Giusti et al. (68), in in vitro and in vivo experiments, it was described that nanoemulsion droplets of an adjuvant are internalized by the lymph node cells. It is still unknown whether internalization in the target cell is required for immune response. However, it is suggested that surfactant molecules contribute to the uptake of nanoemulsion droplets, because they induce cell membrane perturbation, but this is probably not the only mechanism $(66,67)$.

\subsubsection{Antigen-adjuvant interactions}

There are several ways how nanoemulsions can be loaded with an antigen. Antigen can be entrapped in the core of the droplet (encapsulated), chemically conjugated, or it can simply be adsorbed to the surface (61). The main advantage of the entrapment is antigen protection. Also, surface of the droplet can be further decorated (PEGylation, targeting ligands) in order to provide precise delivery. Adsorption considers week interactions between the antigen and the droplet, which are mainly hydrophobic. It is critical in terms of antigen stability, but it is favorable as it needs less processing steps. Chemical conjugation may induce some changes on the antigen epitopes, but it can ensure that the antigen and the nanodroplet will reach the antigen presenting cell at the same time (45). Recent investigations have shown that soft matter particles, such as nanoemulsion droplets, are able to provide efficient immune response even if they are applied independently. Such finding highlighted the potential of nanoemulsions to act as immunopotentiators even in the situations with minimal association with the antigen, e.g. after simple mixing prior to the administration (45, 69).

\subsubsection{Stability of nanoemulsion-based adjuvants}

Nanoemulsion stability is one of the primary concerns for the formulators. Instability can be a consequence of many factors, such as droplet flocculation, coalescence, creaming, Ostwald ripening, as well as chemical degradation, eventually leading to the phase separation. Stability can be optimized by appropriate selection of 
oil, surfactants and aqueous components, along with processing conditions (70). In general, it is checked at $4^{\circ} \mathrm{C}$, room temperature, and at $37^{\circ} \mathrm{C}(63)$.

Oil-in-water nanoemulsions usually show better stability compared to the waterin-oil ones. For instance, stability of water-in-oil Montanide ${ }^{\mathrm{TM}}$ emulsions at room temperature is only several weeks (71). This certainly represents a drawback, but it is not the unique case in the context of pharmaceutical preparations, and it can be overcome by mixing the water phase with the surfactant-oil blend prior to the administration to the patients. Such approach is provided by through and appropriate selection of the oil, surfactants, and their ratio, so that the low-energy mixing can render the emulsion with desired properties. Contrastingly, stability of the oil-in-water nanoemulsions is far better - at room temperature it is more than 2 years $(63,71)$

\subsubsection{Safety profile}

It is often very difficult to define the exact boundaries between immunostimulation and immunotoxicity, in order to reach the perfect balance of efficacy/safety and to comply with strict regulatory standards. Safety of nanoemulsionbased adjuvants is related to the components, their origin and concentration in the formulation $(70,72)$.

Traditional oil adjuvants may induce local and general reactions, such as granuloma, abscesses or fever. Indeed, highly purified non-mineral oils are well tolerated as they are rapidly metabolized and eliminated from the injection site, inducing weaker inflammation (63). Mineral oil stays longer at the injection site and it is eliminated by macrophages, and partially metabolized in fatty acids, triglycerides, phospholipids or sterols. Bollinger et al. (73) demonstrated that $30 \%$ of the mineral oil disappears during the first month and most of the oil found outside the injection site is in the liver and fatty tissues in the form of phospholipids and fatty acids. Stewart-Tull et al. (74) investigated the direct influence of the oil hydrocarbon chain length on the safety of adjuvants, pointing out that small chains are efficient, but induce local reactions, whereas longer chains (more than 14 carbon atoms) are safer, but less efficient. Nevertheless, due to the overall properties (biocompatibility, biodegradability, accessibility and immunostimulation ability), squalene is still the most widely used oil component in nanoemulsion-based adjuvants (70).

The quality of surfactants, as inevitable components of nanoemulsion-based adjuvants, is also important. Up to now, licensed vaccine adjuvants are mostly based on the combination of sorbitan esters and polyoxyethylated soribitan esters, because, in the long run, they have shown to be safe for human use in parenteral formulation and very efficient emulsifiers, rendering stable emulsions with small droplet size.

It should be underlined that development of any vaccine involves secondary processing steps, such as sterilization and usually lyophilization. It is important to 
investigate the influence of these procedures since they can have a major impact on the final vaccine formulations in terms of droplet size, size distribution, stability, and consequently immune responses (61).

\section{Microneedles for vaccine delivery into the skin}

In recent years, numerous disadvantages of parenterally formulated vaccines (e.g., cold storage and transportation system requirements, pain and discomfort during administration, hazardous waste, risk of needle-stick injuries and needle re-use, poor patient compliance and frequently, lack of potent immune response), have enforced the development of innovative technologies to deliver vaccine into the skin, primarily owing to excellent skin immunocompetence and ease of access (75-77). The skin has a dense network of antigen presenting cells - Langerhans cells and dermal dendritic cells, located in epidermis and dermis, respectively - that capture antigens, and upon a proper activation mature, migrate to the draining lymph nodes to activate $\mathrm{T}$ lymphocytes, inducing an adaptive immune response. Also, epidermal keratinocytes, when are in danger, produce a wide variety of cytokines and chemokines (e.g., TNF- $\alpha$ and IL-1 $\beta$ ) as well as antimicrobial peptides, enhancing the maturation of antigen presenting cells and their migration to the lymph nodes $(75,78,79)$. As a result, cutaneous vaccination has been shown to cause similar or better immune response compared to intramuscular injections, even, in some cases, lower antigen doses were used (due to a relatively sparse population of antigen presenting cells in the skeletal muscle compared to the skin) $(76,77)$. However, it should not be forgotten that the superficial skin layer, stratum corneum (SC), which protects the human body against entry of pathogen or toxic substances, represents tremendous physical barrier for efficient vaccine transport into the skin $(76,80)$. Among different strategies investigated to bypass this barrier resistance and to improve the transcutaneous immunization, considerable attention has been recently focused on microneedles.

Microneedles are needle-like structures with lengths in the micrometer range (typically less than 1500 or $2000 \mu \mathrm{m}$ ) that can pierce the SC and create transient microchannels for the antigen delivery into the skin, but without disturbing the nerve endings and blood vessels in the inner viable skin layers $(81,82)$. Consequently, the application of microneedles provides the improved passage for the vaccine antigens towards the immune-competent skin layers in a minimally invasive and painless manner (75). In addition, due to the small size of needles, microneedles administration does not require the professional training and the healthcare personnel and simultaneously, reduces the risk of accidental needle-stick injuries (83). Most importantly, direct targeting of dense network of skin antigen presenting cells using microneedles generally produces higher humoral immune responses compared to conventional intramuscular injections (77). Moreover, it was shown that delivering a subunit protein antigen, ovalbumin, to the 
skin's abundant immune cell population using the coated Nanopatch microneedle array $\left(>21,000 / \mathrm{cm}^{2}\right.$ over $4 \times 4 \mathrm{~mm}$ area; length $\left.110 \mu \mathrm{m}\right)$ significantly enhanced the resultant $\mathrm{CD}^{+} \mathrm{T}$ cell response when compared to standard, intramuscular delivery of both antigen-only and its adjuvanted form, implying its potentially usefulness for improving immunogenicity of vaccine against tuberculosis, HIV and malaria, for which the current vaccine approaches that induce only antibody response are inadequate (84).

In addition, appropriately designed microneedles can generate the strong immune responses without any chemical-based adjuvant or with considerable lower adjuvant doses than required for the intramuscular injection, thus alleviating potential tolerability and safety issues $(76,84)$. Precisely, many of the commonly used vaccine adjuvants may not be compatible with the skin delivery approaches. For example, it was reported that alum, although the most frequently used vaccine adjuvant at the global market, when administered intradermally, might induce the serious side effects, such as persistent intradermal granulomas. On the other hand, advanced biphasic adjuvants (e.g., liposomes, oil-in-water emulsions), may not be sufficiently stable to withstand microneedle production procedure (coating and drying process) $(76,85)$. Hence, if necessary, a wide variety of substances including bacterial ADP-ribosylating exotoxins (Cholera toxin, Escherichia coli heat-labile toxin or their subunits), specific ligands of toll-like receptors [CpG oligodeoxynucleotides, imiquimod, polyinosinic:polycytidylic acid (poly I:C)], Quillaja saponins and others have been utilized in the combination with microneedles as immune enhancing additives to achieve the desirable immune responses (76). However, it should be kept in mind that skin permeability and the degree of vaccine delivery using microneedles can be also influenced by numerous parameters related to the physical properties of microneedle arrays (e.g., height, density, patch area and microneedle geometry) as well as to properties of applicator used for microneedle insertion into the skin $(78,86)$. For example, the length of the microneedles could be an important factor in the selective activation of specific antigen presenting cell population - shorter microneedles could predominately activate Langerhans cells in the epidermis, while longer could mainly affect dermal dendritic cells in the dermis (87). Also, the higher microneedle densities may be beneficial for improving the vaccine immunogenicity, since the skin treatment with microneedles induces the minor damage and cell death and consequently the release of damageassociated molecular patterns, which initiate activation of innate immune response acting as „natural immune enhancer” (78). On the other hand, the proper applicator is neccesarry to ensure the effective, consistent and depth-controlled microneedle penetration into the skin, without the microneedle fracture. Various applicators have been developed (e.g., applicators based on hand-operated rotary application for single microneedle, vibration-based microneedle insertion devices, impact-insertion devices, etc.) and their selection directly depends on the geometry, sharpness and density of the microneedles and the intended use $(86,88)$. 
Up to now, microneedles have been manufactured out of different materials, in a variety of shapes and sizes, depending on the application purpose. In general, all investigated microneedles can be classified in four major groups: solid, coated, dissolving and hollow microneedles (Figure 1) $(82,86)$. The next section deals with each type of microneedles in more detail, along with examples of their use in the vaccine development.

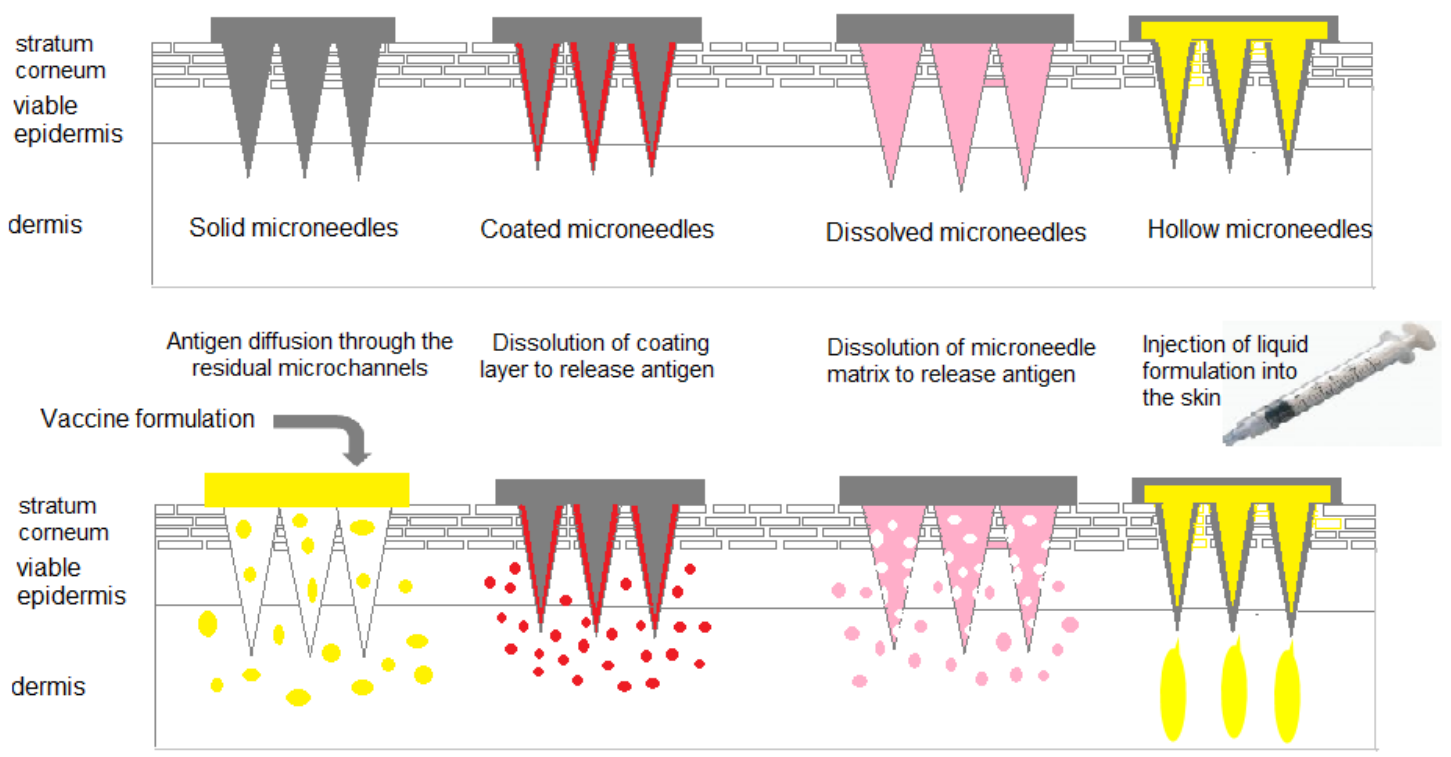

Figure 1. Schematic representation of different microneedle types and methods of antigen delivery into the skin (adopted according to 82, 88, 89, 94)

Slika 1. Šematski prikaz različitih tipova mikroigala i metoda za isporuku antigena u kožu (prilagođeno prema 82, 88, 89, 94)

\subsection{Types of microneedles}

Solid microneedles, as the simplest form of microneedles, were originally used for the skin pretreatment, in the ,poke and patch" approach. After inserting and removing, solid microneedles form transient micropores in the skin surface, enabling the vaccine applied topically, on the treated area, to reach the immunogenic antigen presenting cells located in epidermis and dermis $(82,86,89)$. The first solid microneedles were produced from silicon, but due to its fragile nature and risk of microneedle breaking into the skin, the various materials, such as metals (stainless steel, titanium, tantalum and nickel), ceramics, biodegradable and non-degradable polymers have been studied to ensure the sufficient mechanical strength of microneedles $(82,86)$. Detailed literature review revealed that solid microneedles have been successfully used to deliver the 
various vaccines into the mouse skin in vivo, such as vaccine for diphtheria, influenza, hepatitis B and malaria (79). Among the first, Ding et al. (90) observed that skin perforation with stainless steel microneedles $(4 \times 4$ array on a polymer plate with the surface area of around $0.5 \mathrm{~cm}^{2}$; microneedle length of $300 \mu \mathrm{m}$ ) led to almost 1,000 -fold increase in diphtheria toxoid -specific serum IgG levels after its topical application in mice, compared to intact skin. Furthermore, immune response was further boosted by co-administration of Cholera toxin, indicating that addition of appropriate adjuvant may lower antigen dose required. Interestingly, the same authors observed that microneedle pretreatment had no effect on the immune response to topically applied plain influenza subunit vaccine (91), suggesting that the immune response depends primarily on vaccine type, but also, to certain extent, on the administration procedure. Here, it is worth noting that solid microneedles were also used in the alternative ,scrape and patch" approach, involving skin scrapping with blunt-tipped microneedles to generate microabrasions of the SC before the vaccine application onto the skin surface $(79,86)$. This approach was tested with Onvax ${ }^{\mathrm{TM}}$ microneedles (Becton Dickinson, USA) (an array of plastic microprojections with a height of $\sim 200 \mu \mathrm{m})$ to improve delivery of a rabies vaccine in humans, but no protective immune responses were detected, probably due to its inefficient delivery into the epidermis $(79,86,92)$. However, it should be noted that, despite some promising results, the popularity of solid microneedles for improving vaccine delivery into the skin has declined in recent years, predominately due to cumbersome two-step administration process, inconsistent results and consequently, increased interest in other types of microneedles $(79,82,93)$.

Advancement on classical solid microneedles was development of ,coat and poke" approach, which involves pre-coating of microneedle arrays by suitable, watersoluble vaccine formulation that rapidly dissolves upon microneedles insertion into the skin (before the removal from the skin). In this way, solid microneedles are utilized not only to perforate the skin, but also, as vehicles to carry and deliver antigens directly into this skin, offering simplified (one-step) vaccination procedure (79, 82, 86, 94). However, it should be kept in mind that small antigen dose (typically less than $1 \mathrm{mg}$ ) can be administered via coated microneedles, due to the limited dimensions of microneedles shaft and tip - thick coatings are generally accompanied with a very low skin delivery efficacy because of a reduced sharpness of microneedle arrays $(82,86)$. Composition of coating solution depends on the nature and type of antigen investigated and commonly includes viscosity enhancer (e.g., carboxymethylcellulose (CMC), methylcellulose) to achieve sufficient thickness of coating layer, stabilizing saccharide (e.g., trehalose, sucrose) to retain activity of antigen during drying/storage and surfactant (e.g., poloxamers) to decrease the surface tension and thus to assure uniform coating efficiency $(95,96)$. Additionally, Choi and co-workers (97) observed that addition of viscosity enhancers was necessary to reduce the osmotic stress (caused by high concentrations of sugars) and to preserve activity of completely inactivated 
influenza virus during the microneedle coating. Furthermore, the presence of viscosity enhancer improved systemic immune response and ensured better protection against the viral challenge $(95,97)$. On the other hand, owing to inherent stability and viscosity, DNA vaccines can be coated onto microneedles without stabilizers and viscosity enhancers (98). For example, Song et al. (98) observed that metal microneedles (length of $750 \mu \mathrm{m}$ ) coated with solution of plasmid DNA vaccine encoding the influenza hemagglutinin (excipient free coatings) induced higher humoral and cellular immune responses as well as better protective immunity compared to conventional i.m. immunization. Alternatively, in order to improve the coating efficiency, it was proposed to perform the pre-coating of microneedle surface with $\mathrm{SiO}_{2}$, polylactic-co-glycolic acid (PLGA) or polyvinylpyrrolidone (PVP) or by the formation of polyelectrolyte coatings with microencapsulation properties (e.g., polydi(carboxylatophenoxy)phosphazene, chitosan and $\mathrm{CMC}$ ). Interestingly, it was observed that some of these pre-coatings were capable to improve the vaccine stability and exhibit adjuvant effect $(85,86)$. Finally, it is worth mentioning that although coated microneedles were successfully used to deliver various antigens into the skin of different animal models (e.g., influenza, human papillomavirus, West Nile virus, rotavirus, herpes simplex virus, hepatitis B and C, bacillus Calmette-Guerin, measles and polio viruses), inducing better or equal immune response compared to parenteral needle-based immunization, literature review revealed no clinical trials pertaining to vaccine delivery via coated microneedles (79).

Opposite to the solid/coated microneedles, dissolving microneedles consist of water soluble or biodegradable materials (e.g., polymers, sugars), enabling the antigen encapsulation within the microneedle matrix. After insertion into the skin, dissolving microneedles completely dissolve/degrade into the skin, simultaneously releasing incorporated antigen (,poke and release" approach) $(82,86)$. Consequently, this approach offers numerous distinct advantages such as improved antigen stability, selfadministration and absence of biohazardous sharp waste and safe disposal of remaining part $(78,79,82,86)$. However, there are also important challenges in the microneedle preparation which limit their widespread use, such as antigen wastage (due to low volume filling of the microcavities used for micromolding preparation procedure), insufficient antigen and adjuvant loading (due to low volumes of microneedle tips), antigen degradation and sterility $(78,86)$. The dissolving microneedles have been usually fabricated from sodium hyaluronate and $\mathrm{CMC}$, as inactive materials approved by FDA for parenteral drug products, but also from other polymers (e.g., poly(vinylalcohol), PVP, methylvinylether-co-maleic anhydride) and low molecular weight sugars (e.g., maltose, trehalose). Biodegradable polymers such as PLGA, polylactic acid and polyglycolic acid are not advisable as the matrix material due to their slow dissolution rate in skin and a fabrication method involving high temperatures and organic solvents (78). Up to now, different vaccine types, ranging from proteins and peptides to DNA vectors encoding antigenic proteins and attenuated or inactivated 
viruses, have been encapsulated in the microneedle matrix by direct dispersing into polymer, or by incorporating into nanoparticles or into a cross-linked structure to boost immune response. Numerous studies have shown that dissolving microneedles, depending on the antigen type, induced comparable or better humoral and/or cellular immune responses than s.c., i.m. or traditional i.d. injection of the same antigen dose. Furthermore, a considerable improvement of immune response was observed when adjuvants, compatible with skin administration route (e.g., $\mathrm{CpG}$, poly(I:C), Quil-A, monophosphoryl lipid A and imiquimod) were added (78). Finally, it is important to emphasize that dissolving microneedles represent a relatively new vaccine delivery platform and there are no authorized products on the market. However, there are a few clinical studies examining (i) the effect of microneedle patch on local skin reactions, reliability of use and acceptability to patients $(99,100)$ as well as (ii) efficacy of novel transcutaneous influenza vaccine based on dissolving microneedles containing trivalent influenza hemagglutinins relative to subcutaneous injections of each influenza antigen (101). Obtained results suggested that investigated microneedle patches were generally well tolerated in the skin, with only mild erythema localized to treated site that resolved fully within seven days $(78,99)$. Furthermore, administration of influenza vaccines to human subjects via dissolving microneedles induced high level of immunity, proving that dissolving microneedles are promising for practical use as an easy and effective method to replace conventional injections systems (100).

Hollow microneedles have an empty space inside and hole at the tip, enabling the passive diffusion, or alternatively, active pressure-driven flow of a liquid formulation into the skin (,poke and flow" approach). The latter can be achieved by combining microneedles with external pressure device, such as syringe, pump, or pressurized gas (86). Hollow microneedles have been commonly made from silicon, glass, polymer and metal, in two designs, as a single microneedle (mimicking the conventional hypodermic needle) and an array of multiple microneedles. Increase in the number of microneedles per patch enables the simultaneous application of vaccine formulation over the wider skin area, thus potentially enhancing the likelihood of lymphatic uptake of presented antigens (86). The important advantage of this approach lies in a possibility of using the existing injectable formulations, but there are no opportunities to administer dry-state vaccine formulations which permit to improve the antigen stability and avoid cold storage and transportation system. Additional limitation of this approach is relatively low diffusion rate that can be potentially overcome by partial retraction or by adding hyaluronidase to the infusion solution (to degrade the hyaluronic acid within skin collagen fibers) $(86,102)$. Also, hollow microneedles are associated with less patient convenience compared to other microneedle types $(82,94)$. Hollow microneedles have been used to immunize human volunteers with polio and influenza vaccines, but also other antigens have been successfully delivered into the skin of various animal models (79). In this sense, it is interesting to note that, currently, there are few commercially 
available hollow microneedle devices: (i) Soluvia ${ }^{\mathrm{TM}}$ Microinjection System (Becton Dickinson, USA), consisting of single silicon needle (length $1500 \mu \mathrm{m}$ ) coupled with a pre-fillable injection system, has been marked for delivery of influenza vaccination (other trade names are Intanza ${ }^{\circledR}$; IDflu ${ }^{\circledR}$ and Fluzone Intradermal ${ }^{\circledR}$ by Sanofi Pasteur) (ii) MicronJet $^{\circledR}$ (NanoPass, Israel), consisting of four hollow silicon microneedles (length $600 \mu \mathrm{m}$ ) arranged on a plastic adaptor for the use with a standard syringe, has also obtained FDA approval (iii) 3M $\mathrm{M}^{\mathrm{TM}}$ Hollow Microstructured Transdermal System (hMTS) (3M, USA) comprising 12 polymer microneedles (length $1500 \mu \mathrm{m}$ ), is intended for clinical studies $(81,88,103)$.

To conclude, in the era of modern vaccinology, it is a must to define optimal balance between efficacy and safety of an adjuvant, in order to provide potent and safe vaccines. Relying on already established approaches, some innovative adjuvants and vaccine delivery systems are presented in this work. It remains that intense multidisciplinary research provides new perspectives in this field.

\section{Acknowledgement}

This work was supported by the project TR34031, funded by Ministry of Education, Science and Technological Development, Republic of Serbia and through the activities within the framework of the COST Action 16231 European Network of Vaccine Adjuvants (ENOVA).

\section{References}

1. European Pharmacopoeia, 9th ed. Strasbourg: Council of Europe, 2016.

2. Memorandum of Understanding for the implementation of the COST Action "European Network of Vaccine Adjuvants" (ENOVA) CA16231. COST Association AISBL, 23.06.2017.

3. Allen LVJ, Ansel HC. Ansel's Pharmaceutical Dosage Forms and Drug Delivery Systems. 10th ed. Philadelphia: Lippincott Williams \& Wilkins; 2014.

4. Committee for medicinal products for human use (CHMP). Guideline on adjuvants in vaccines for human use, EMEA/CHMP/VEG/134716/2004, 2004.

5. Pati R, Shevtsov M, Sonawane A. Nanoparticle Vaccines Against Infectious Diseases. Front Immunol. 2018;9:2224. 
6. Garçon N, Friede M. Evolution of adjuvants across the centuries. In: Plotkin S, Orenstein W, Offit P, Edwards KM, $7^{\text {th }}$, editor(s). Plotkin's Vaccines (Seventh Edition). Elsevier; 2018; p. 61-74.e4

7. Lindblad EB, Duroux L. Mineral Adjuvants. In: Schijns VEJC, O'Hagan DT, $2^{\text {nd }}$, editors. Immunopotentiators in modern vaccines. Elsevier; 2005; p. 347-375.

8. Li X, Wang X, Ito A. Tailoring inorganic nanoadjuvants towards next-generation vaccines. Chem Soc Rev. 2018;47(13):4954-4980.

9. HogenEsch H, O'Hagan DT, Fox CB. Optimizing the utilization of aluminum adjuvants in vaccines: you might just get what you want. NJP Vaccines 2018;3(1):51.

10. Thakkar SG, Cui Z. Methods to Prepare Aluminum Salt-Adjuvanted Vaccines. Methods Mol Biol. 2017;1494:181-199.

11. Hem SL, HogenEsch H. Relationship between physical and chemical properties of aluminumcontaining adjuvants and immunopotentiation. Expert Rev Vaccines. 2007;6(5):685-98.

12. Sun B, Xia T. Nanomaterial-based vaccine adjuvants. J Mater Chem B. 2016;4(33):5496-5509.

13. Kolade OO, Jin W, Tengroth C, Green KD, Bracewell DG. Shear effects on aluminum phosphate adjuvant particle properties in vaccine drug products. J Pharm Sci. 2015;104(2):378-87.

14. Shardlow E, Mold M, Exley C. From stock bottle to vaccine: elucidating the particle size distributions of aluminum adjuvants using dynamic light scattering. Front Chem. 2016;4:48.

15. Caulfield MJ, Shi L, Wang S, Wang B, Tobery TW, Mach H, et al. Effect of alternative aluminum adjuvants on the absorption and immunogenicity of HPV16 L1 VLPs in mice. Hum Vaccin. 2007;3(4):139-45.

16. Shi S, Zhu H, Xia X, Liang Z, Ma X, Sun B. Vaccine adjuvants: understanding the structure and mechanism of adjuvanticity. Vaccine. 2019;37(24):3167-3178.

17. Morefield GL. A rational, systematic approach for the development of vaccine formulations. AAPS J. 2011;13(2):191-200.

18. Dey AK, Malyala P, Singh M. Physicochemical and functional characterization of vaccine antigens and adjuvants. Expert Rev Vaccines. 2014;13(5):671-85.

19. Hem SL, HogenEsch H. Aluminum-containing adjuvants: properties, formulation, and use. In: Singh M, editor. Vaccine Adjuvants and Delivery Systems. John Wiley \& Sons, Inc.; 2007; p. 81114.

20. Iyer S, HogenEsch H, Hem SL. Effect of the degree of phosphate substitution in aluminum hydroxide adjuvant on the adsorption of phosphorylated proteins. Pharm Dev Technol. 2003;8(1):81-6.

21. Ahl PL, Wang SC, Chintala R, Mensch C, Smith WJ, Wenger M2, Blue J3. Quantitative analysis of vaccine antigen adsorption to aluminum adjuvant using an automated high throughput method. PDA J Pharm Sci Technol. 2018;72(2):149-162.

22. Kristensen D, Chen D, Cummings R. Vaccine stabilization: research, commercialization, and potential impact. Vaccine 2011;29(41):7122-4. 
23. Galazka A, Milstein J, Zaffran M. Thermostability of vaccines. Geneva, Switzerland: World Health Organization; 1998.

24. Li X, Thakkar SG, Ruwona TB, Williams RO 3rd, Cui Z. A method of lyophilizing vaccines containing aluminum salts into a dry powder without causing particle aggregation or decreasing the immunogenicity following reconstitution. J Control Release. 2015;204:38-50.

25. Masson JD, Thibaudon M, Bélec L, Crépeaux G. Calcium phosphate: a substitute for aluminum adjuvants? Expert Rev Vaccines. 2017;16(3):289-299.

26. Yang JH, Lee JH, Ryu HJ, Elzatahry AA, Alothman ZA, Choy JH: Drug-clay nanohybrids as sustained delivery systems. Appl Clay Sci. 2016;130:20-32.

27. Garcia-Villen F, Carazo E, Borrego-Sánchez A, Sánchez-Espejo R, Cerezo P Viseras C, Aguzzi C. Clay minerals in drug delivery systems. In: Mercurio M, Sarkar B, Langella A, editors. Modified Clay and Zeolite Nanocomposite Materials, Environmental and Pharmaceutical Applications. Elsevier; 2019; p.129-166.

28. Krajišnik D, Daković A, Janićijević J, Milić J. Natural and Modified Silica-Based Materials as Carriers for NSAIDs. In: Čalija B, editor. Microsized and Nanosized Carriers for Nonsteroidal Anti-Inflammatory Drugs: Formulation Challenges and Potential Benefits. Elsevier Academic Press; 2017; p. 219-258.

29. Pilar A, Darder M, Wicklein B, Rytwo G, Ruiz-Hitzky E. Clay-Organic Interfaces for Design of Functional Hybrid Materials. In: Delville MH, Taubert A, $1^{\text {st }}$, editors. Hybrid Organic-Inorganic Interfaces: Towards Advanced Functional Materials. Wiley-VCH Verlag GmbH \& Co. KGaA; 2017; p. 1-84.

30. Ruiz-Hitzky E, Darder M, Fernandes FM, Wicklein B, Alcântara ACS, Aranda P. Fibrous clays based bionanocomposites, Prog Polym Sci. 2013;38 (10-11):1392-1414.

31. Wicklein B, Martín del Burgo MÁ, Yuste M, Darder M, Escrig Llavata C, Aranda P, Ortín J, del Real G, Ruiz-Hitzky E. Lipid-based bio-nanohybrids for functional stabilisation of influenza vaccines. Eur J Inorg Chem. 2012;5186-91.

32. Clapp T, Siebert P, Chen D, Jones Braun L. Vaccines with aluminum-containing adjuvants: optimizing vaccine efficacy and thermal stability. J Pharm Sci. 2011;100(2):388-401.

33. Fujimori A, Arai S, Soutome Y, Hashimoto M. Improvement of thermal stability of enzyme via immobilization on Langmuir-Blodgett films of organo-modified aluminosilicate with high coverage. Colloids Surf A Physicochem Eng Asp 2014; 448,45-52.

34. Chen W, Zuo H, Li B, Duan C, Rolfe B, Zhang B, Mahony TJ, Xu ZP. Clay Nanoparticles Elicit Long-Term Immune Responses by Forming Biodegradable Depots for Sustained Antigen Stimulation. Small. 2018;14(19):e1704465.

35. Mody KT, Popat A, Mahony D, Cavallaro AS, Yu C, Mitter N. Mesoporous silica nanoparticles as antigen carriers and adjuvants for vaccine delivery. Nanoscale. 2013;5(12):5167-79. 
36. $\mathrm{Xu} \mathrm{W,} \mathrm{Riikonen} \mathrm{J,} \mathrm{Lehto} \mathrm{VP.} \mathrm{Mesoporous} \mathrm{systems} \mathrm{for} \mathrm{poorly} \mathrm{soluble} \mathrm{drugs.} \mathrm{Int} \mathrm{J} \mathrm{Pharm.}$ 2013;453(1):181-197.

37. Milic J, Čalija B, Đorđević S. Diversity and Functionality of Excipients for Micro/Nanosized Drug Carriers. In: Bojan Čalija, editor. Microsized and Nanosized Carriers for Nonsteroidal AntiInflammatory Drugs: Formulation Challenges and Potential Benefits. Elsevier Academic Press; 2017; 95-132.

38. Mahony D, Cavallaro AS, Stahr F, Mahony TJ, Qiao SZ, Mitter N. Mesoporous silica nanoparticles act as a self-adjuvant for ovalbumin model antigen in mice. Small. 2013;9(18):313846.

39. Kim J, Li WA, Choi Y, Lewin SA, Verbeke CS, Dranoff G, Mooney DJ. Injectable, spontaneously assembling, inorganic scaffolds modulate immune cells in vivo and increase vaccine efficacy. Nat Biotechnol. 2015;33(1):64-72.

40. Xu C, Lei C, Yu C. Mesoporous Silica Nanoparticles for Protein Protection and Delivery. Front Chem. 2019;7:290.

41. Simon-Yarza T, Mielcarek A, Couvreur P, Serre C. Nanoparticles of metal-organic frameworks: on the road to in vivo efficacy in biomedicine. Adv Mater. 2018;30(37):e1707365.

42. Mamo T, Poland GA. Nanovaccinology: the next generation of vaccines meets $21^{\text {st }}$ century materials science and engineering. Vaccine. 2012;30: 6609-6611.

43. Saroja $\mathrm{CH}$, Lakshmi PK, Bhaskaran S. Recent trends in vaccine delivery systems: a review. Int J Pharm Ivest. 2011;1(2):64-74.

44. Wallis J, Shenton DP, Carlisle RC. Novel approaches for the design, delivery and administration of vaccine technologies. Clin Exp Immunol. 2019;196(2):189-204.

45. Zhao L, Seth A, Wibowo N, Zhao CX, Mitter N, Yu C, Middelberg A P. Nanoparticle vaccines. Vaccine. 2014;32(3):327-337.

46. Iyer V, Cayatte C, Guzman B, Schneider-Ohrum K, Matuszak R, Snell A. et al. Impact of formulation and particle size on stability and immunogenicity of oil-in-water emulsion adjuvants. Hum Vaccin Immunother. 2015;11(7):1853-1864.

47. Singh Y, Meher JG, Raval K, Khan FA, Chaurasia M, Jain NK, Chourasia MK. Nanoemulsion: Concepts, development and applications in drug delivery. J Control Release. 2017;252: 28-49.

48. Tadros T, Izquierdo P, Esquena J, Solans C. Formation and stability of nano-emulsions. Adv Colloid Int Sci. 2004;108 -109: 303-318.

49. Bonferoni MC, Rossi S, Sandri G, Ferrari F, Gavini E, Rassu G, Giunchedi, P. Nanoemulsions for „Nose-to-Brain” Drug Delivery. Pharmaceutics. 2019;11(2): 84.

50. Ilić T, Savić S, Batinić B, Marković B, Schmidberger M, Lunter D. et al. Combined use of biocompatible nanoemulsions and solid microneedles to improve transport of a model NSAID across the skin: In vitro and in vivo studies. Eur J Pharm Sci. 2018;125:110-119. 
51. Zhang J, Miao J, Han X, Lu Y, Deng B, Lv F. et al. Development of a novel oil-in-water emulsion and evaluation of its potential adjuvant function in a swine influenza vaccine in mice. BMC Vet Res. 2018;14(1), 415-426.

52. Đorđević SM, Santrač A, Cekić ND, Marković BD, Divović B, Ilić TM et al. Parenteral nanoemulsions of risperidone for enhanced brain delivery in acute psychosis: Physicochemical and in vivo performances. Int J Pharm. 2017;533(2):421-430.

53. Yao K, McClements DJ, Xiang J, Zhang Z, Cao Y, Xiao H, Liu, X. Improvement of carotenoid bioaccessibility from spinach by co-ingesting with excipient nanoemulsions: Impact of oil phase composition. Food \& Funct. 2019;10: 5302-5311.

54. Aboalnaja KO, Yaghmoor S, Kumosani TA, McClements D. J. Utilization of nanoemulsions to enhance bioactivity of pharmaceuticals, supplements, and nutraceuticals: Nanoemulsion delivery systems and nanoemulsion excipient systems. Expert Opin Drug Deliv. 2016;13(9):1327-1336.

55. Helgeson ME. Colloidal behaviour of nanoemulsions: Interactions, structure, and rheology. Curr Opin Colloid Interface Sci. 2016; 25: 39-50.

56. Komaiko, JS, McClements DJ. Formation of food-grade nanoemulsions using low-energy preparation methods: A review of available methods. Compr Rev Food Sci F. 2016;15(2): 331-352.

57. Anton N, Vandamme TF. Nano-emulsions and Micro-emulsions: Clarifications of the Critical Differences. Pharm Res. 2009;28(5), 978-985.

58. O’Hagan DT, Ott GS, Nest GV, Rappuoli R, Giudice GD. The history of MF59® adjuvant: a phoenix that arose from the ashes. Expert Rev Vaccines. 2013; 12(1):13-30.

59. Freund J, Casals J, Hosmer EP. Sensitization and antibody formation after injection of tubercle bacilli and paraffin oil. Proc Soc Exp Biol Med. 1937;37:509-513.

60. Leroux-Roels G. Unmet needs in modern vaccinology: adjuvants to improve the immune response. Vaccine. 2010; 28: C25-C36.

61. Oyewumi MO, Kumar A, Cui Z. Nano-microparticles as immune adjuvants: correlating particle sizes and the resultant immune responses. Expert Rev Vaccines. 2010;9(9):1095-1107.

62. Del Giudice G, Rappuoli R, Didierlaurent AM. Correlates of adjuvanticity: a review on adjuvants in licensed vaccines. Semin Immunol. 2018; 39:14-21

63. Aucouturier J, Dupuis L, Ganne V. Adjuvants designed for veterinary and human vaccines. Vaccine. 2001;19(17-19):2666-2672.

64. Shah RR, O'Hagan DT, Amiji MM, Brito L. A. The impact of size on particulate vaccine adjuvants. Nanomedicine. 2014;9(17):2671-2681.

65. Niikura K, Matsunaga T, Suzuki T, Kobayashi S, Yamaguchi H, Orba Y. et al. Gold nanoparticles as a vaccine platform: influence of size and shape on immunological responses in vitro and in vivo. ACS nano. 2013; 7(5): 3926-3938. 
66. Shah RR, Taccone M, Monaci E, Brito LA, Bonci A, O'Hagan DT. et al. The droplet size of emulsion adjuvants has significant impact on their potency, due to differences in immune cellrecruitment and-activation. Sci Rep. 2019; 9(1), 1-9.

67. Calabro S, Tritto E, Pezzotti A, Taccone M, Muzzi A, Bertholet S. et al. The adjuvant effect of MF59 is due to the oil-in-water emulsion formulation, none of the individual components induce a comparable adjuvant effect. Vaccine. 2013;31(33):3363-3369.

68. Giusti F, Seubert A, Cantisani R, Tortoli M, D’Oro U, Ferlenghi I. et al. Ultrastructural visualization of vaccine adjuvant uptake in vitro and in vivo. Microsc Microanal. 2015;21(4):791795.

69. Morel S, Didierlaurent A, Bourguignon P, Delhaye S, Baras B, Jacob V. et al. Adjuvant System AS03 containing $\alpha$-tocopherol modulates innate immune response and leads to improved adaptive immunity. Vaccine. 2011;29(13):2461-2473.

70. Fox C. Squalene emulsions for parenteral vaccine and drug delivery. Molecules. 2009;14(9):3286331.

71. Aucouturier J, Dupuis L, Deville S, Ascarateil S, Ganne V. Montanide ISA 720 and 51: a new generation of water in oil emulsions as adjuvants for human vaccines. Expert Rev Vaccines. 2002;1(1): 111-118.

72. Batista-Duharte A, Lindblad EB, Oviedo-Orta E. Progress in understanding adjuvant immunotoxicity mechanisms. Toxicol Lett. 2011;203(2): 97-105.

73. Bollinger J. N. Metabolic fate of mineral oil adjuvants using 14C-labeled tracers I: mineral oil. J Pharm Sci. 1970; 59(8): 1084-1088.

74. Stewart-Tull DES, Shimono T, Kotani S, Knights BA. Immimosuppressive Effect in Mycobacterial Adjuvant Emulsions of Mineral Oils Containing Low Molecular Weight Hydrocarbons. Int Arch Allerg Immunol, 1976;52(1-4): 118-128.

75. Ita K. Transdermal delivery of vaccines - Recent progress and critical issues. Biomed Pharmacother. 2016;83:1080-1088.

76. Engelke L, Winter G, Hook S, Engert J. Recent insights into cutaneous immunization: How to vaccinate via the skin. Vaccine. 2015;33(37):4663-74.

77. Suh H, Shin J, Kim YC. Microneedle patches for vaccine delivery. Clin Exp Vaccine Res. 2014;3(1):42-9.

78. Leone M, Mönkäre J, Bouwstra JA, Kersten G. Dissolving Microneedle patches for dermal vaccination. Pharm Res. 2017;34(11):2223-2240.

79. Marshall S, Sahm LJ, Moore AC. The success of microneedle-mediated vaccine delivery into skin. Hum Vaccin Immunother. 2016;12(11):2975-2983.

80. Gill HS, Kang SM, Quan FS, Compans RW. Cutaneous immunization: an evolving paradigm in influenza vaccines. Expert Opin Drug Deliv. 2014 Apr;11(4):615-27. 
81. Duarah S, Sharma M, Wen J. Recent advances in microneedle-based drug delivery: special emphasis on its use in paediatric population. Eur J Pharm Biopharm. 2019; 136:48-69.

82. Kim YC, Park JH, Prausnitz MR. Microneedles for drug and vaccine delivery. Adv Drug Deliv Rev. 2012;64(14):1547-68.

83. Hiraishi Y, Nandakumar S, Choi SO, Lee JW, Kim YC, Posey JE, Sable SB, Prausnitz MR. Bacillus Calmette-Guérin vaccination using a microneedle patch. Vaccine. 2011;29(14):2626-36.

84. $\mathrm{Ng} \mathrm{HI}$, Fernando GJ, Kendall MA. Induction of potent $\mathrm{CD}^{+} \mathrm{T}$ cell responses through the delivery of subunit protein vaccines to skin antigen-presenting cells using densely packed microprojection arrays. J Control Release. 2012;162(3):477-84.

85. Andrianov AK, DeCollibus DP, Gillis HA, Kha HH, Marin A, Prausnitz MR, Babiuk LA, Townsend H, Mutwiri G. Poly[di(carboxylatophenoxy)phosphazene] is a potent adjuvant for intradermal immunization. Proc Natl Acad Sci U S A. 2009;106(45):18936-41.

86. van der Maaden K, Jiskoot W, Bouwstra J. Microneedle technologies for (trans)dermal drug and vaccine delivery. J Control Release. 2012;161(2):645-55.

87. Romgens AM, Bader DL, Bouwstra JA, Oomens CW. Predicting the optimal geometry of microneedles and their array for dermal vaccination using a computational model. Comput Methods Biomech Biomed Engin. 2016;19(15):1599-609.

88. Kolli CS. Microneedles: bench to bedside. Ther Deliv. 2015;6(9):1081-8.

89. Shin CI, Jeong SD, Rejinold NS, Kim YC. Microneedles for vaccine delivery: challenges and future perspectives. Ther Deliv. 2017;8(6):447-460.

90. Ding Z, Van Riet E, Romeijn S, Kersten GF, Jiskoot W, Bouwstra JA. Immune modulation by adjuvants combined with diphtheria toxoid administered topically in BALB/c mice after microneedle array pretreatment. Pharm Res. 2009a;26(7):1635-43.

91. Ding Z, Verbaan FJ, Bivas-Benita M, Bungener L, Huckriede A, van den Berg DJ, Kersten G, Bouwstra JA. Microneedle arrays for the transcutaneous immunization of diphtheria and influenza in BALB/c mice. J Control Release. 2009b;136(1):71-8.

92. Laurent PE, Bourhy H, Fantino M, Alchas P, Mikszta JA. Safety and efficacy of novel dermal and epidermal microneedle delivery systems for rabies vaccination in healthy adults. Vaccine. 2010;28(36):5850-6.

93. Hao Y, Li W, Zhou X, Yang F, Qian Z. Microneedles-based transdermal drug delivery systems: a review. J Biomed Nanotechnol. 2017;13(12):1581-1597.

94. Rejinold NS, Shin JH, Seok HY, Kim YC. Biomedical applications of microneedles in therapeutics: recent advancements and implications in drug delivery. Expert Opin Drug Deliv. 2016;13(1):109-31.

95. Tomar J, Born PA, Frijlink HW, Hinrichs WL. Dry influenza vaccines: towards a stable, effective and convenient alternative to conventional parenteral influenza vaccination. Expert Rev Vaccines. 2016;15(11):1431-1447. 
96. Zaric M, Ibarzo Yus B, Kalcheva PP, Klavinskis LS. Microneedle-mediated delivery of viral vectored vaccines. Expert Opin Drug Deliv. 2017;14(10):1177-1187.

97. Choi HJ, Song JM, Bondy BJ, Compans RW, Kang S-M, Prausnitz MR. Effect of osmotic pressure on the stability of whole inactivated influenza vaccine for coating on microneedles. PLoS One. 2015; 10(7):e0134431.

98. Song JM, Kim YC, O E, Compans RW, Prausnitz MR, Kang SM. DNA vaccination in the skin using microneedles improves protection against influenza. Mol Ther. 2012;20(7):1472-80.

99. Arya J, Henry S, Kalluri H, McAllister DV, Pewin WP, Prausnitz MR. Tolerability, usability and acceptability of dissolving microneedle patch administration in human subjects. Biomaterials. 2017;128:1-7.

100. Hirobe S, Azukizawa H, Matsuo K, Zhai Y, Quan YS, Kamiyama F, et al. Development and clinical study of a self-dissolving microneedle patch for transcutaneous immunization device. Pharm Res. 2013;30(10):2664-74.

101. Hirobe S, Azukizawa H, Hanafusa T, Matsuo K, Quan YS, Kamiyama F, et al. Clinical study and stability assessment of a novel transcutaneous influenza vaccination using a dissolving microneedle patch. Biomaterials. 2015;57:50-8.

102. Martanto W, Moore JS, Kashlan O, Kamath R, Wang PM, O'Neal JM, Prausnitz MR Microinfusion using hollow microneedles. Pharm Res. 2006;23(1):104-113.

103. Waghule T, Singhvi G, Dubey SK, Pandey MM, Gupta G, Singh M, Dua K. Microneedles: A smart approach and increasing potential for transdermal drug delivery system. Biomed Pharmacother. 2019;109:1249-1258. 


\title{
Konvencionalni i napredni adjuvansi u formulacijama vakcina: mineralni adsorbenti, nanočestični nosači i sistemi tipa mikroigala
}

\author{
Danina Krajišnik, Tanja Ilić, Ines Nikolić, Snežana Savić ${ }^{*}$ \\ ${ }^{1}$ Univerzitet u Belgradu - Farmaceutski fakultet, Katedra za farmaceutsku tehnologiju i \\ kozmetologiju, Vojvode Stepe 450, 11221 Beograd, Srbija
}

*Autor za korespondenciju: Prof. dr Snežana Savić, Tel.: +381-11-3951288

e-mail: snezana.savic@pharmacy.bg.ac.rs

\begin{abstract}
Kratak sadržaj
U doba savremene vakcinologije, ograničena imunogenost većine korišćenih antigena podstakla je primenu različitih adjuvanasa u formulacijama vakcina radi postizanja željenog imunskog odgovora. Mineralni adjuvansi na bazi aluminijuma su istorijski najčešće korišćeni imunostimulansi u vakcinama i smatraju se generalno bezbednim za humanu upotrebu. Značajni napredak na polju sinteze, kontrole strukture i funkcionalnog dizajna neorganskih (nano)materijala uslovio je povećano interesovanje za primenom inovativnih adjuvanasa kao što su gline, mezoporozne silika nanočestice, nanočestice cink-oksida, gvožđe oksida i gvožđe hidroksida, i dr. Sa druge strane, uočava se i sve veće interesovanje za primenom specifičnih nanonosača antigena, kao što su nanoemulzije, kako bi se antigeni zaštitili od preuranjene proteolitičke degradacije i/ili poboljšala njihova imunogenost, olakšavanjem preuzimanja i obrade od strane antigen-prezentujućih ćelija. Takođe, brojni istraživački napori tokom poslednjih nekoliko godina usmereni su ka razvoju inovativnih tehnologija za isporuku antigena u kožu (kao što su mikroigle) radi poboljšanja efikasnosti vakcinacije uz istovremeno povećanje adherence pacijenata, posebno u pedijatrijskoj populaciji (neinvazivan ili minimalno invazivan način primene). Otuda, u ovom preglednom radu dat je detaljan pregled karakteristika svakog od navedenih pristupa za poboljšanje efikasnosti vakcina, sa posebnim osvrtom na primere njihove primene $u$ formulacijama vakcina i faktore koji određuju efikasnost $\mathrm{i}$ bezbednost.
\end{abstract}

Ključne reči: formulacija vakcina, adjuvansi, mineralni adsorbenti, nanoemulzije, mikroigle 